\title{
Characterization of Reclaimed Asphalt Pavement (RAP) as a road pavement material (National Road Waru, Sidoarjo)
}

\author{
Ari Widayanti ${ }^{1,{ }^{*}}$, Ria A. A. Soemitro ${ }^{1}$, Januarti Jaya Ekaputri1, and Hitapria Suprayitno ${ }^{1}$ \\ ${ }^{1}$ Institut Teknologi Sepuluh Nopember, Depart. Civil Enginering, Surabaya, Indonesia
}

\begin{abstract}
Reclaimed Asphalt Pavement (RAP) is a dredging pavement material using Cold Milling Machine. The application of Reclaimed Asphalt Pavement is increased year by year. Due to the increasing application of RAP year by year which implicates environment condition, especially in damaging natural resources, the research on material used in RAP needs to be conducted, so RAP can be optimally utilized. To achieve optimal performance, data of RAP characteristics reviewed from microstructural analysis is necessary. The objective of this research is to obtain the characteristics of Reclaimed Asphalt Pavement. The method used was literary study based on previous research. Material tests used were XRF, SEM and FTIR. The object of study was RAP material taken from national road Waru Sidoarjo. The major compositions of Reclaimed Asphalt Pavement obtained were Kaolin, Lithium, Tetraborate, Dextrin. SEM graphics showed the morphological and surface texture of RAP. FTIR graphic presented the functional group of Reclaimed Asphalt Pavement showing O-H C-O acid in the peak of graphic. From XRD result, the major compounds of Reclaimed Asphalt Pavement obtained were Calcium, Sodium, Aluminum, Silicate.
\end{abstract}

\section{Introduction}

Road is one of the supporting infrastructure to support community activities. Reclaimed Asphalt Pavement is a dredging road pavement material using Cold Milling Machine. The accumulation of Reclaimed Asphalt Pavement materials is averages 50000 ton/annual, in order to optimize RAP utilization efforts [1].

Thought to process and utilize Reclaimed Asphalt Pavement in other countries has been widely studied. Many countries such as America, India, Taiwan and Japan used $10-40 \%$ of RAP as road pavement. Even in Singapore has managed to utilize RAP of $100 \%$ for pavement layer material. Based on research [2] in the FHA/Federal Highway Administration and NCHRP/National Highway Cooperative Research Program (provide input to AASHTO to update existing standards for use of Reclaimed Asphalt Pavement). Use of RAP is limited to the base and usage. RAP in road pavement that requires new material should also. Reclaimed Asphalt Pavement percentage is used 25-30\% in 2010,

* Corresponding author: ariwidayanti1973@gmail.com 
even close to 50\%. RAP usage application can be up to $30 \%$ for surface layer on Asphalt Concrete, $100 \%$ RAP in hot mix, warm and cold mix on low traffic road, parking area, bicycle and pedestrian area. Use of $30 \%$ RAP on base and sub base on primary road, and use $100 \%$ RAP on the shoulder of the road [3]. Use of RAP must be cost effective, environmental friendly and produce optimum performance of pavement layers.

Some research results that have been done include testing the nature of RAP by mixing RAP with lime added materials. From this mixing result, obtained asphalt pavement extracted asphalt pavement equal to $4.16 \%$. The addition of lime is $4.5 \%$. From the test results obtained increase in mixed properties can be improved by gradation engineering and lime addition [4].

The other research used RAP with $20 \%$, the addition of filler fly ash by $4 \%, 5 \%, 6 \%$. From the results of this research, the use of RAP $20 \%$ with the most optimal mixed performance result is $5 \%$ filler can produce flow, stability Marshall in accordance with standard [5]. The use of $25 \%$ reclaimed asphalt pavement can meet the requirements of grain AC-WC gradation resulting in 6\% Optimum Bitumen Content with 60-70\% and 5.9\% asphalt Pen with asphalt TRS 55 type modification [6]. The composition of $20 \%$ RAP from Pilang - Probolinggo road, $6.5 \%$ coarse aggregate, $25 \%$ medium aggregate, $45 \%$ fine aggregate and $1 \%$ cement in hot asphalt mixture with modified asphalt can meet the requirements of asphalt concrete layer with Optimum Bitument Content $5.6 \%$ with synthetic Elastomeric asphalt and $6.2 \%$ with asphalt processed [7].

Initial mixing with $40 \%$ RAP and $60 \%$ new material is had consideration of aging effect of pavement layer. Optimum composition is obtained 30\% RAP Gemekan - Jombang road and $70 \%$ new material with Optimum Bitumen Content of $5.70 \%$. While $20 \%$ RAP and 80\% new material with Optimum Bitumen Content 5.9\% [8]. Composition 25\% RAP Pandaan - Malang road and $75 \%$ new material with abrasion value of $19.73 \%$ meet the requirements of specification with Optimum Bitumen Content of $6.35 \%$ [9].

Replacement of $100 \%$ RAP granular material yields the highest score on Indirect Tensile Strength and Modulus Resilient in both dry and wet conditions. The comparable condition is to use Pen asphalt $60 / 70$ and $80 / 100$, and the better one is to use asphalt Pen 80/100 [10]. Comparison of Reclaimed Asphalt Pavement between 0\%, 10\%, 20\%, 30\%, $40 \%, 100 \%$ and natural materials for hot mix asphalt using 60/70. The result is that the percentage of Reclaimed Asphalt Pavement of 30\% yields high stability value, and on the other hand increases the possibility of brittle effect on highway pavement mix [11].

Addition of Reclaimed Asphalt Pavement by 20\% improves all properties of the asphalt mixture. The addition of Reclaimed Asphalt Pavement produces better performance than using only natural aggregates [12]. Use of 30-48\% Reclaimed Asphalt Pavement exhibits better properties (volumetric properties, mechanical and performance properties) than using natural materials [13].

Research in the laboratory used the percentage of RAP by $10 \%, 20 \%, 30 \%, 40 \%$ RAP. There is no consistency of change in addition to physical properties (penetration, ductility, softening point) on the mixture. RAP usage ranges within $10-40 \%$ can be adopted for use on new roads using RAP [14]. Increasing the percentage of RAP on a mixture is containing tire waste, indicating a higher stability value. The addition of RAP with tire wastes results in a good workability score. The addition of tire waste can increase the resistance to be able to withstand deformation due to traffic load [15].

Addition of RAP by $25 \%$ with tire waste variation can add resilient modulus value to temperature variation. This addition is also recommended for areas with high temperature tropical climate. Addition of RAP and tire waste influence the technical life of road and its resistance to fatigue [16].

Chemical composition was obtained by XRF test. The minerals and morphology of material are obtained by XRD and SEM test. The results of the XRF test obtained Calcium 
Oxide and Iron Oxide are the two major chemical formers of EAF and BOF slag. The results of XRD show both BOF and EAF slag samples are very complex, with many peak points, of many types of minerals in the sample. XRD analysis showed the presence of $\mathrm{MgO}$ and $\mathrm{CaO}$ in $\mathrm{BOF}$ and EAF sample slag. The SEM micro graph shows the majority of the sand sizes of steel slags are sub angular to the angular. It shows very rough surface texture with different crystal structures. The characteristics of steel slag samples are considered in more detail for review of steel slag properties [17].

Many countries have used RAP, especially to improve the performance of road pavement quality. Compared to the use of natural materials, using RAP has more benefits, such as to save natural materials in which it affects to the sustainability of the environment. These studies review the application of RAP in some countries with a percentage of use from $0 \%$ to $100 \%$ depending on the source of the RAP and part of the road pavement layer. However, testing of RAP characteristic has not been done in detail. Therefore, it is necessary to test of the RAP material microstructural to support better material properties results, in this case the focus of the review on the performance of composite materials and the attachment between combining material with each other.

\section{Discussion}

\subsection{Method}

RAP material can be obtained from milling in Waru National Road - Sidoarjo. Dredging process of road pavement used Cold Milling Machine. The RAP sample was broken and ground to fine powder. The figure of RAP material is given in Figure 1.

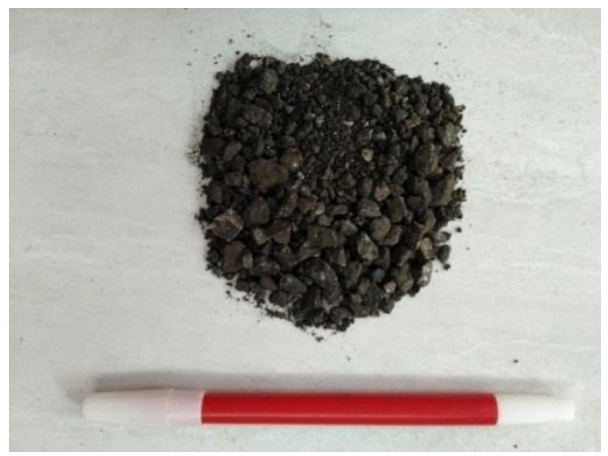

Figure 1 Reclaimed asphalt pavement material

Materials test consist of XRF (X-Ray Fluorescence), XRD (X-Ray Diffraction), SEM (Scanning Electron Microscopy) and FTIR (Fourier Transform Infra Red). XRD, FTIR and SEM test did in Material and Metallurgy Laboratory, Institut Teknologi Sepuluh Nopember Surabaya. XRF test did in Energy and Environmental Laboratory, Institut Teknologi Sepuluh Nopember Surabaya.

\subsection{Analysis}

\subsubsection{XRF analysis}

RAP material can be obtained from road national Waru, Sidoarjo Indonesia. Material test used XRF (X-Ray Fluorescence). The chemical composition of Reclaimed Asphalt Pavement can be presented in Table 1. 
Table 1. Element Compound of Reclaimed Asphalt Pavement

\begin{tabular}{|c|r|}
\hline Element Compound & Test result (\% by weight) \\
\hline $\mathrm{SiO}_{2}$ & 38 \\
\hline $\mathrm{Fe}_{2} \mathrm{O}_{3}$ & 26.8 \\
\hline $\mathrm{CaO}$ & 16.3 \\
\hline $\mathrm{Al}_{2} \mathrm{O}_{3}$ & 11 \\
\hline $\mathrm{SO}_{3}$ & 2.9 \\
\hline $\mathrm{TiO}_{2}$ & 1.8 \\
\hline $\mathrm{K}_{2} \mathrm{O}$ & 1.73 \\
\hline $\mathrm{MnO}$ & 0.585 \\
\hline $\mathrm{SrO}$ & 0.37 \\
\hline $\mathrm{CuO}$ & 0.13 \\
\hline $\mathrm{V}_{2} \mathrm{O}_{5}$ & 0.11 \\
\hline $\mathrm{BaO}$ & 0.2 \\
\hline $\mathrm{Re}_{2} \mathrm{O}_{7}$ & 0.06 \\
\hline $\mathrm{ZrO}_{2}$ & 0.055 \\
\hline $\mathrm{ZnO}$ & 0.045 \\
\hline
\end{tabular}

Based on XRF test in Table 1 can be obtained major element compound of RAP consist of $\mathrm{SiO}_{2}, \mathrm{Fe}_{2} \mathrm{O}_{3}, \mathrm{CaO}$ by weight percentage. Material with high $\mathrm{SiO}_{2}$ content will produce hard material, commonly found in nature as sand or quartz. For road pavement, this material is water-absorbing or hygroscopic. Relating to its capacity as a refractory material, it can be used as high temperatures protection. $\mathrm{SiO}_{2}$ has more different crystalline forms (polymorphs) than amorphous forms.

Table 2. Oxide compound of reclaimed asphalt pavement

\begin{tabular}{|c|r|}
\hline Oxide Compound & Test result (\% by weight) \\
\hline $\mathrm{Fe}$ & 36.6 \\
\hline $\mathrm{Si}$ & 26.7 \\
\hline $\mathrm{Ca}$ & 19.8 \\
\hline $\mathrm{Al}$ & 8.3 \\
\hline $\mathrm{K}$ & 2.36 \\
\hline $\mathrm{Ti}$ & 1.92 \\
\hline $\mathrm{S}$ & 1.9 \\
\hline $\mathrm{Mn}$ & 0.868 \\
\hline $\mathrm{Sr}$ & 0.65 \\
\hline $\mathrm{Ba}$ & 0.4 \\
\hline $\mathrm{Cu}$ & 0.22 \\
\hline $\mathrm{V}$ & 0.11 \\
\hline $\mathrm{Zn}$ & 0.096 \\
\hline $\mathrm{Zr}$ & 0.083 \\
\hline $\mathrm{Re}$ & 0.06 \\
\hline
\end{tabular}

Based on XRF test in Table 2 can be obtained major oxide compound of RAP consist of $\mathrm{Si}, \mathrm{Fe}$ and $\mathrm{Ca}$ by weight percentage. Silica is hard mineral, chemical inert (no reaction to 
any chemicals), and has low melting point. Its condition shows the strong bond among thatoms.
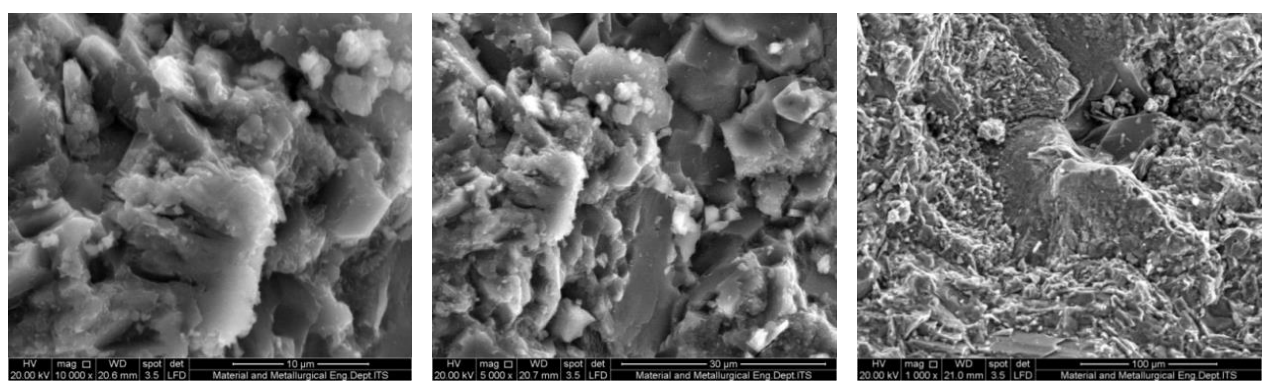

Figure 2. SEM micrograph of reclaimed asphalt pavement (1000x, 5000x, 10000x)

\subsubsection{SEM analysis}

The SEM image for the RAP sample is presented in Figure 2. It shows morphology and surface texture of RAP material.

The SEM micrographs shows that the majority of Reclaimed Asphalt Pavement materials were sub-angular and angular, very rough surface textures and good to be used in road pavement as it improved the interlocking aggregate in road pavement material as well as the asphalt concrete mixtures quality.

\subsubsection{FTIR analysis}

An FTIR analysis was performed on Spectrum RAP. FTIR spectrometer in the range of $4000-400 \mathrm{~cm}^{-1}$ at room temperature. The result of FTIR analysis can be presented in Table 3.

Table 3. FTIR Test Result of RAP

\begin{tabular}{|c|c|l|}
\hline Index & Match & \multicolumn{1}{|c|}{ Compound Name } \\
\hline 18452 & 35.30 & Kaolin \\
\hline 18201 & 34.95 & Lithium tetraborate \\
\hline 1151 & 34.55 & Dextrin \\
\hline 18371 & 33.76 & Potassium heptafluoroborate \\
\hline 18206 & 33.71 & Ammonium tetrafluoroborate \\
\hline 49 & 33.63 & TRANS-PIPERYLENE \\
\hline 18162 & 33.31 & Metaphosphoric acid \\
\hline 1579 & 33.17 & Glyoxal trimeric dihydrate \\
\hline 18280 & 32.28 & Ammonium-d4 dideuteriumphosphate \\
\hline 18292 & 32.13 & Sodium bismuthate \\
\hline
\end{tabular}




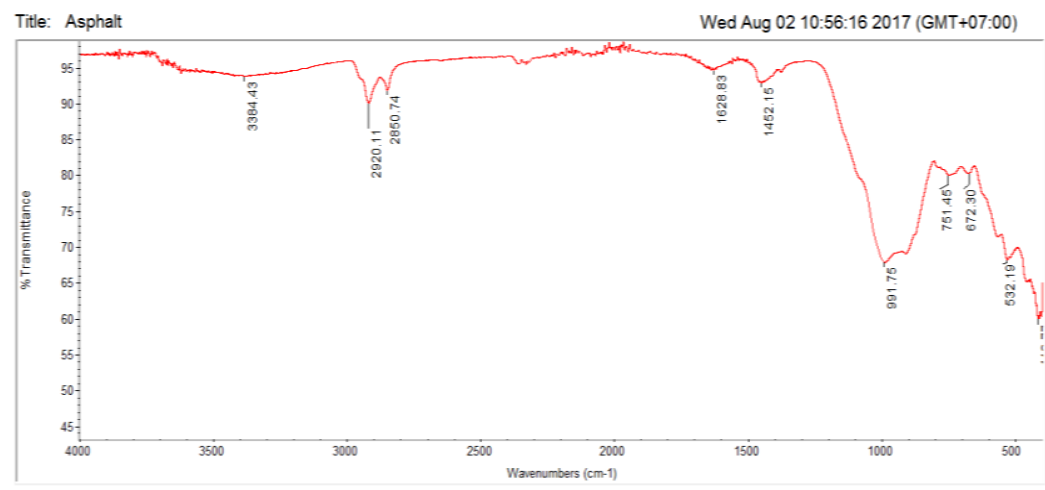

Figure 3 FTIR spectra of reclaimed asphalt pavement sample

Figure 3 shows that FTIR spectrum of the RAP sample. The strong peak at $\sim 1000 \mathrm{~cm}^{-1}$ was related to Al-O and Si-O asymmetric stretching vibrations. The bands seen bond molecule of RAP. It shows O-H C-O acid.

Table 4 Wavenumber of FTIR result

\begin{tabular}{|c|c|c|}
\hline Wavenumber $\left(\mathrm{cm}^{-1}\right)$ & Functional Group & Peak Description \\
\hline 3384.43 & O-H (alcohol) & Strong and broad \\
\hline 2920.11 & C-H $\left(\mathrm{sp}^{3}\right.$ carbon $)$ & Strong, broad and multi banded \\
\hline 2850.74 & C-H $\left(\mathrm{sp}^{3}\right.$ carbon $)$ & Strong, broad and multi banded \\
\hline 1628.83 & C=C (alkene, aromatic ring) & \\
\hline 1452.15 & & \\
\hline 991.75 & & Strong \\
\hline 751.45 & Phenyl group & Strong \\
\hline 672.30 & Phenyl group & \\
\hline 532.19 & & \\
\hline
\end{tabular}

\subsubsection{XRD analysis}

XRD analysis was presented in Figure 4 and Table 4.

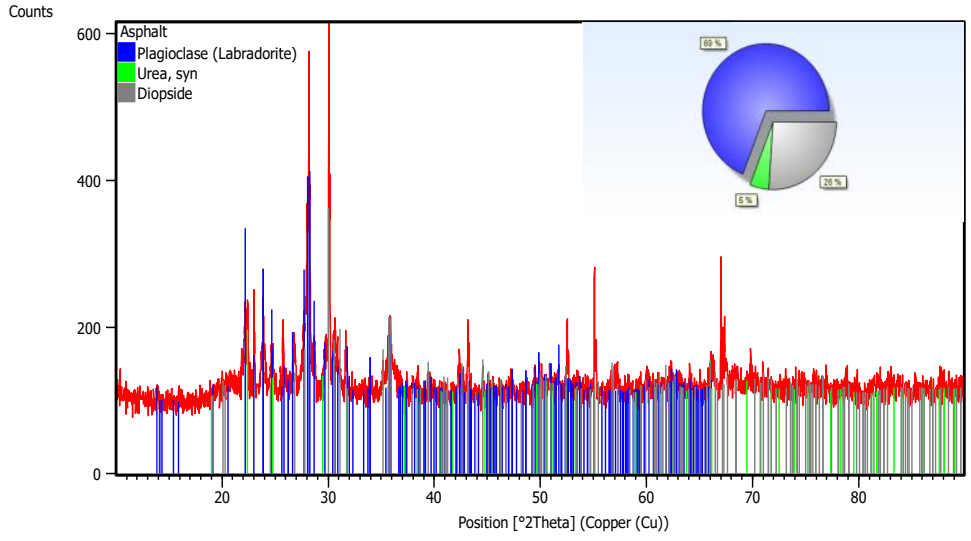


Figure 4. XRD of reclaimed asphalt pavement sample

Table 5. Result of XRD test

\begin{tabular}{|c|c|c|c|c|c|}
\hline Ref. Code & Score & Compound Name & $\begin{array}{c}\text { Displacement } \\
\left({ }^{0} 2 \mathrm{Th}\right)\end{array}$ & $\begin{array}{c}\text { Scale } \\
\text { Factor }\end{array}$ & Chemical Formula \\
\hline $\begin{array}{c}01-083- \\
1370\end{array}$ & 45 & $\begin{array}{l}\text { Calcium } \\
\text { Sodium } \\
\text { Aluminum } \\
\text { Silicate }\end{array}$ & 0.213 & 0.484 & $\begin{array}{l}\text { Ca } 0.65 \\
\text { Na } 0.35 \\
(\text { Al } 1.65 \\
\text { Si } 2.35 \\
\text { O 8) }\end{array}$ \\
\hline $\begin{array}{c}01-089- \\
2835\end{array}$ & 21 & Urea & 0.203 & 0.124 & $\mathrm{CO}\left(\mathrm{NH}_{2}\right)_{2}$ \\
\hline $\begin{array}{c}01-083- \\
1392\end{array}$ & 20 & $\begin{array}{l}\text { Magnesium } \\
\text { Iron Calcium } \\
\text { Sodium } \\
\text { Silicate }\end{array}$ & 0.180 & 0.404 & $\begin{array}{l}(\mathrm{Mg} 0.964 \\
\mathrm{Fe} 0.036) \\
(\mathrm{Ca} 0.94 \\
\mathrm{Na} 0.06) \\
\left(\mathrm{Si}_{2} \mathrm{O} 6\right)\end{array}$ \\
\hline
\end{tabular}

\section{Conclusions}

In conclusions, the results of this research were:

1. Major compositions of Reclaimed Asphalt Pavement in object taken were Kaolin, Lithium Tetraborate and Dextrin

2. SEM graphic presented morphology and surface texture of Reclaimed Asphalt Pavement. The SEM micrographs showed majority of Reclaimed Asphalt Pavement material were sub-angular and angular and very rough surface texture which were good to be road pavement structure because it improved the interlocking aggregate in road pavement material

3. Reclaimed Asphalt Pavement molecule banding at peak graphic showed O-H (alcohol) and $\mathrm{C}-\mathrm{H}$ (carbon).

4. XRD result showed that the major components of RAP were Calcium, Sodium, Aluminum, Silicate.

\section{Acknowledgements}

The research in degree scholarship is provided by LPDP/Fund Managers - Ministry of Finance, Indonesia.

\section{References}

1. Budianto, Herry, Menuju Jalan yang Andal (2009)

2. Cooper, S.J, 'Asphalt Pavement Recycling with Reclaimed Asphalt Pavement (RAP)' (2011)

3. Widger, A., Skilnick, F, Utilization of Recycled Asphalt in Cold Mixes and Cold in Place Recycling Processes Guidelines. Clifton Associates Ltd.(2012)

4. Astuti, W.W., Sunarjono, S., Sutanto, M.H, 'Analisis Pengaruh Bahan Tambah Kapur terhadap Karakterisrik RAP (Reclaimed Asphalt Pavement)'. (2015)

5. Handayani, R, 'Analisa Penggunaan Reclaimed Asphalt Pavement (RAP) sebagai Bahan Campuran Beraspal Panas Tipe Asphalt Concrete-Binder Course (ACBC) dengan Menggunakan Fly Ash (Studi Kasus Ruas Jalan Taman Waru)'(2016) 
6. Harahab, S, Soemitro, R.A., Budianto, H, 'Optimalisasi Penggunaan Reclaimed Asphalt Pavement (RAP) sebagai Bahan Campuran Beraspal Panas (Asphaltic Concrete) Tipe AC-Wearing Course (AC-WC) Gradasi Kasar dengan Aspal Pen 6070 dan Aspal Modifikasi Jenis TRS 55 (Studi Kasus Jalan Nasional Pandaan-Malang dan Jalan Nasional Pilang-Probolinggo)'. (2013)

7. Herawati, N. Soemitro, R.A.A., Budianto, H, 'Analisis Penentuan Komposisi Optimal Penggunaan Reclaimed Asphalt Pavement (RAP) sebagai Bahan Campuran Beraspal Panas (Asphaltic Concrete) Menggunakan Aspal Modifikasi (Studi Kasus Jalan Pilang - Probolinggo)'. (2012)

8. Kusmarini, E.P., Soemitro, R.A.A., Budianto, H, 'Analisis Penggunaan Reclaimed Asphalt Pavement (RAP) dan Aspal Pen 60 - 70 sebagai Bahan Campuran Beraspal Panas (Asphaltic Concrete) (Studi Kasus Ruas Jalan Gemekan - Jombang dan Pandaan - Malang)'(2012)

9. Falevi, R, 'Optimalisasi Penggunaan Reclaimed Asphalt Pavement (RAP) sebagai Bahan Campuran Beraspal Panas (Asphaltic Concrete) Tipe AC-Wearing Course (AC-WC) Gradasi Halus dengan Menggunakan Aspal Pen 60-70 Variasi Abrasi Agregat Baru (Studi Kasus Jalan Nasional Pandaan - Malang)'(2012)

10. Ortiz, O. R., Berardinelli, A., Carvajal-Munoz, Fuentes, L.G, Evaluation of 'Hot Mix Asphalt Mixtures with Replacement of Aggregates by Reclaimed Asphalt Pavement (RAP) Material'. (2012)

11. Parveez, P., Srikanta, Y., Konnur, D, 'Study on the Effect of Reclaimed Asphalt Pavement (RAP) on the Mechanical Behaviour of Hot Mix Asphalt'(2008)

12. Pradyumna, T.A., Mittal, A., Jain, P.K 'Characterization of Reclaimed Asphalt Pavement (RAP) for Use in Bituminous Road Construction '(2013)

13. Shen, J., Amirkhanian, S., Aune, J.M,Effects Of Rejuvenatin Agents Of Superpave Mixtures Containing Reclaimed Asphalt Pavement'. (2007)

14. Sunil, S. Mallesh, K.M., Chandrasekaraiah 'Experimental Investigation on The Perfomance of Bituminous Mixes wth Reclaimed Asphalt Pavement (RAP) Materials (Case Study Tumkur to Chidradurga-NH4)'. IJRET: International Journal of Research in Engineering Technology 0306 (2014)

15. Xiao, F., Amirkhanian, S.N., Shen, J., Putman, B, 'Influences of Crumb Rubber Size and Type on Reclaimed Asphalt Pavement (RAP) Mixtures'. (2009)

16. Xiao, F., Amirkhanian, S., Juang, C. H, Rutting Resistance of Rubberized Asphalt Concrete Pavements Containing Reclaimed Asphalt Pavement Mixtures'. Journal of Materials in Civil Engineering (2007)

17. Yildirim, I.Z., Prezzi, M. 2011. 'Chemical, Mineralogical, and Morphological Properties of Steel Slag’. 2011 (2011) 